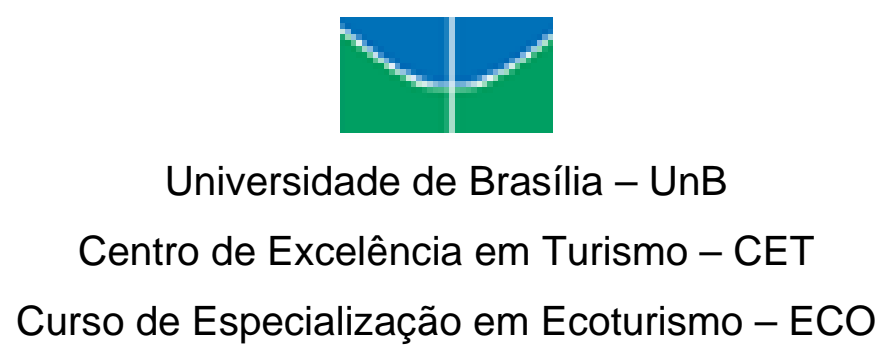

\title{
MARKETING EM PROJETOS TURÍSTICOS: UM COMPARATIVO DA UTILIZAÇÃO DA FERRAMENTA DE PROMOÇÃO DOS EMPREENDIMENTOS - APA CHAPADA IMPERIAL E HOTEL- FAZENDA VELHA
}

\author{
Weliton Querino da Silva \\ Orientador: Prof. Ms. Gilson Z. Borda
}

Banca: Prof. Ms. Sérgio S. Salvati

Brasília - DF

Agosto, 2004 
Universidade de Brasília - UnB

Centro de Excelência em Turismo - CET

Curso de Especialização em Ecoturismo - ECO

\title{
MARKETING EM PROJETOS TURÍSTICOS: UM COMPARATIVO DA UTILIZAÇÃO DA FERRAMENTA DE PROMOÇÃO DOS EMPREENDIMENTOS - APA CHAPADA IMPERIAL E HOTEL- FAZENDA VELHA
}

Weliton Querino da Silva

\author{
Banca Examinadora \\ Gilson Zehetmeier Borda, Mestre \\ Orientador
}

Monografia apresentada ao Centro de Excelência em Turismo da Universidade de Brasília como requisito parcial para obtenção do certificado de Especialista em Ecoturismo.

Brasília - DF

Agosto, 2004 
Silva, Weliton

Marketing em projetos turísticos: um comparativo da utilização da ferramenta de promoção dos empreendimentos - APA Chapada Imperial e Hotelfazenda Velha / Weliton Silva. Brasília, 2004.

$47 \mathrm{f}$.

Monografia (especialização) - Universidade de Brasília, Centro de Excelência em Turismo, Curso de Especialização Latu Sensu em Ecoturismo, 2004.

Orientador: Prof. Ms. Gilson Zehetmeier Borda.

I. Ecoturismo. II. Marketing. III. Promoção. 
Weliton Querino da Silva

MARKETING EM PROJETOS TURÍSTICOS: UM COMPARATIVO DA UTILIZAÇÃO DA FERRAMENTA DE PROMOÇÃO DOS EMPREENDIMENTOS - APA CHAPADA IMPERIAL E HOTELFAZENDA VELHA

Comissão Avaliadora

\author{
Gilson Z. Borda, Mestre \\ Orientador
}

Prof.

Prof.

Brasília - DF

Agosto, 2004 
Dedico esse trabalho à minha querida esposa Luciana que com seu carinho, paciência e compreensão me deu forças para continuar estudando. 


\section{Agradecimentos}

Ao professor Mestre Gilson G. Borda, pelo apoio e confiança;

À Direção do CET, pelo apoio e estímulo;

Ao demais professores, pelos valiosos ensinamentos. 


\section{Resumo}

Visto que o segmento turístico movimenta todo um setor da atividade econômica, é necessário o uso de ferramentas de marketing de maneira a alavancar a visibilidade dos projetos ecoturísticos surgidos nos últimos tempos. Partindo do conceito de que o marketing utiliza ferramentas de promoção do produto e/ou serviço de forma a mostrar ao consumidor suas vantagens, é fundamental que os empreendimentos diretamente envolvidos com essa atividade lancem mão de tais instrumentos para auferir os ganhos que o sistema proporciona. O trabalho busca identificar as principais estratégias mercadológicas utilizadas pelos empreendimentos APA Chapada Imperial e Hotel-fazenda Velha, com vistas a promover os serviços turísticos oferecidos nessas unidades. Através de pesquisa exploratória descritiva, foi possível verificar as principais ferramentas e estratégias utilizadas para a promoção desses empreendimentos. 


\section{Abstract}

As the tourist segment moves a part of the economic activity, the use of instruments of marketing is necessary in order to increase the visibility of the projects of ecological tourism that recently appeared. Leaving of the concept of that the marketing uses instruments of promotion of the product and/or service to show to the consumer its advantages, it is basic that the enterprises involved in this activity use these instruments in order to obtain the profits that the system provides. This work searchs to identify the main strategies of marketing used by the enterprises APA Chapada Imperial and Hotel Fazenda Velha, in order to promote their tourist services. Through the descriptive research, it was possible to verify the main instruments and strategies used to promote these enterprises. 


\section{Sumário}

1. JUSTIFICATIVA 10

2. OBJETIVOS

A) GERAL 11

B) ESPECÍFICOS

3. REVISÃO DE LITERATURA 11

3.1 TURISMO

3.2 ECOTURISMO 13

3.3 MARKETING 17

3.4 MARKETING DE SERVIÇOS 22

3.4.1 Enfoque promocional 24

3.5 MARKETING TURÍSTICO 30

3.6 PRODUTO TURÍSTICO 32

4. METODOLOGIA 35

5. UNIVERSO DA PESQUISA 36

6. APRESENTAÇÃO E ANÁLISE 38

7. CONSIDERAÇÕES FINAIS 44

8. REFERÊNCIAS BIBLIOGRÁFICAS 46

ANEXO 49 


\section{Justificativa}

O turismo é o maior dos movimentos da história da humanidade e se caracteriza por sua taxa de crescimento constante. Ele responde a uma série de necessidades humanas: de espaço, movimento, bem-estar, expansão e repouso, longe das tarefas impostas pelo trabalho cotidiano ou rotina. Hoje o turismo não é privilégio de algumas classes. Trata-se de um movimento "sem classes", que graças à política dos "pacotes turísticos", proporciona a possibilidade de viajar a quase todas as pessoas, tornando-se, cada vez mais, uma reivindicação e um direito do homem civilizado.

O marketing turístico é segundo Krippendorf (2003), "a adaptação sistemática e coordenada da política das empresas de turismo, tanto privadas como do Estado, no plano local, regional, nacional e internacional, visando à satisfação das necessidades de determinados grupos de consumidores, obtendo, com isso, um lucro apropriado".

Tendo em vista a importância do segmento turístico e levando em consideração que essa indústria movimenta todo um setor da atividade econômica, é necessário o uso de ferramentas de marketing de maneira a alavancar a visibilidade dos projetos ecoturísticos que tem surgido nos últimos tempos. Partindo do conceito de que o marketing utiliza ferramentas de promoção do produto e/ou serviço de forma a mostrar ao consumidor as vantagens que tal produto/serviço oferece, é fundamental que os empreendimentos diretamente envolvidos com essa atividade lancem mão de tais instrumentos para auferir as vantagens que o sistema proporciona.

O presente trabalho busca identificar as principais estratégias mercadológicas utilizadas pelos empreendimentos APA Chapada Imperial e Hotelfazenda Velha, com vistas a promover os serviços turísticos oferecidos nessas unidades. Tal identificação se deu devido ao fato de que essa atividade tem alcançado grande expressividade na região do entorno do Distrito Federal, se tornando uma atividade altamente promissora. Tal fator traz ainda a possibilidade de exploração sustentável da vegetação do cerrado, bem como propicia a geração de emprego e renda para as comunidades rurais, ampliando a possibilidade de fazer com que essas famílias usufruam de melhor qualidade de vida. 


\section{Objetivos}

\section{a) Geral}

- Analisar a aplicação da ferramenta de marketing sob o enfoque da promoção nos empreendimentos ecoturísticos - APA Chapada Imperial e Hotel-fazenda Velha.

\section{b) Específicos}

- Estudar os principais autores da área;

- Verificar quais as ferramentas de comunicação utilizadas;

- Comparar as ferramentas utilizadas por cada empreendimento.

\section{Revisão de literatura}

\subsection{Turismo}

Conforme dados da Organização Mundial de Turismo, o turismo, movimenta mais de US\$ 3,5 trilhões anualmente, além de ser considerado por vários órgãos de pesquisa como um dos ramos de atividade comercial que mais cresce no mundo. Calcula-se que mais de 180 milhões de pessoas vivam direta ou indiretamente desta atividade. (OMT, 2001)

Devido a esse crescimento, o turismo vem gerando interesses distintos e, por isto, passou a ser segmentado em diferentes áreas de atuação. Surgiram assim o turismo cultural, o turismo religioso, o turismo esportivo, o turismo infantil, o turismo da terceira idade, o turismo gastronômico, o turismo rural e o turismo ecológico ou ecoturismo, que vem se desenvolvendo muito nos últimos anos, principalmente em países com grande diversidade de recursos naturais. O Brasil, 
em especial, possui grandes áreas naturais e uma importante característica: é o país de maior biodiversidade do globo, o que o torna um dos maiores potenciais para esta nova forma de turismo. (Silveira, 1999)

Dentro do contexto de que o turismo inicialmente esteve mais voltado para uma orientação econômica, Laje e Milone (2000), afirmam que:

\begin{abstract}
"o turismo não precisa ter um conceito absoluto, mas importa no conhecimento do mecanismo dinâmico que integra. Especificamente sob a análise da teoria microeconômica, quando aplicada a um estudo do setor turístico particular, por se tratar de uma abordagem restrita do comportamento dos indivíduos e das empresas, não se incorporando aspectos globais, pode ser estudada em três partes: demanda, oferta e mercado turístico".
\end{abstract}

Não é difícil observar que as primeiras publicações relativas ao turismo o conceituavam como um fenômeno econômico. Mais adiante, conforme comenta Acerenza (2002), não contrariando o interesse econômico do turismo, mas complementar a esse aspecto, há o entendimento de que o turismo tem sua origem no próprio ser humano, que se constitui no elemento principal. Surge, então, novos estudos com base na psicologia e enfatiza as motivações dos deslocamentos dos turistas.

Ainda segundo Acerenza (2002), o estudo do turismo como fenômeno, apesar de se considerar o homem como o elemento mais importante, não pode ser enfocado do ponto de vista do indivíduo. De acordo com Fuster apud Acerenza (2002), "o turismo é, na realidade, o resultado de uma soma de visões particulares de um grande conjunto de indivíduos que exercem influências entre si, até formar uma visão geral, universal, social" . Portanto, um enforque sociológico.

Por fim, como último enfoque, há de se considerar que o turismo existe num espaço geográfico. São implicações espaciais importantes, que as ciências geográficas estudam a partir dos deslocamentos dos indivíduos e ocupações desses ambientes. 
Por tudo isso, pode-se perceber e analisar a atividade turística como um fenômeno complexo, interdependente, muito mais abrangente, portanto, apreciado pelo enfoque de sistema.

O turismo não se manifesta de forma isolada. Todas os elementos do meio ambiente natural, da vida pessoal e da organização social se interligam e interagem, se articulam entre si formando um sistema para a produção de atividades turísticas.

\subsection{Ecoturismo}

O ecoturismo é caracterizado "como um segmento da atividade turística que utiliza forma sustentável o patrimônio natural e cultural, incentiva sua conservação e busca a formação de uma consciência ambientalista através da interpretação do ambiente, promovendo o bem-estar das populações envolvidas". (Embratur, 1994)

Este conceito, definido contextualmente pela Embratur, logicamente não deixa de conter os princípios básicos do ecoturismo, que é o incentivo para a consciência ambientalista ou conservacionista do ambiente, assim como também a promoção do bem-estar das populações que estão sendo inseridas, residentes no local. E é neste perfil, principalmente o das populações e do seu meio modificado ou não, pelas atividades antrópicas, que as atividades ecoturísticas devem se encarregar de conservar e divulgar na sua prática. Por isso que a partir do momento em que uma atividade for colocada em uma determinada região, esta deve obrigatoriamente, inserir de forma sustentável, as populações que ali vivem, e primordialmente se estas retiram suas necessidades do próprio cotidiano local naquele ecossistema.

Existem também outras formas de expressar ou conceituar as formas de atuação do ecoturismo, como por exemplo, a de que esta atividade é considerada um ato de busca de lugares exóticos e remotos na natureza, para o qual o homem "ecoturista" se faça um desafiante daquele espetáculo da natureza predominante que, acima de tudo deve ser observada e conservada. Deve-se lembrar de que esta linha ilógica deste conceito prático, que está sendo mais utilizado na atualidade capitalista, em que boa parte da iniciativa privada atuante na área desfruta com muito prazer. Atuam, esquecendo na maioria das vezes da 
conscientização e inserção das populações locais juntamente com todos os seus processos culturais e históricos.

A modalidade de turismo denominada turismo ecológico, ou simplesmente ecoturismo, constitui-se um dos alicerces na tentativa de alcançar um modelo sustentável de desenvolvimento. Por ecoturismo pode-se entender que ele é uma "viagem responsável a áreas naturais, visando preservar o meio ambiente e promover o bem-estar da população local". (Western, 1999) É um fenômeno característico do final do século XX, e ao que se percebe do século XXI.

O século $X X$ vislumbrou a evolução do ecoturismo além da significativa mudança das excursões às áreas naturais. O maior exemplo disto é observado na África. Os safáris de caça que se realizavam no começo do século $X X$ com o intuito de capturar grandes cabeças de animais como rinocerontes, leões ou elefantes, dizimavam grandes populações desses animais ano a ano. Com o passar das décadas foram substituídos por safáris fotográficos que já eram comuns nos anos 60. Percebeu-se que esses animais vivos eram mais lucrativos do que mortos. Para que o ecoturismo alcançasse as dimensões de hoje, o trabalho das Organizações Não Governamentais - ONGs - foi também fundamental. Outro grande impulsionador do turismo ecológico foi sem dúvida os documentários em vídeo sobre viagens e a natureza, populares nos finais da década de 70.

No entanto, o turismo de massa a essas áreas continuou por muito tempo depredando habitats naturais, molestando animais, destruindo a natureza e muitas culturas. Felizmente o comportamento foi sendo mudado e os visitantes hoje estão mais conscientes do valor das diferentes formas de vida, do dano ecológico e cultural que podem provocar.

Para que o turismo se desenvolva de maneira que se preserve sua atratibilidade, ou seja, que ao longo do tempo, seus atrativos continuem intactos e motivando a vinda de turistas, é necessário muito cuidado no planejamento. Para isso, deve ser elaborado um detalhado Plano de Desenvolvimento Turístico, que é entendido como uma ordenação das "ações do homem sobre o território e ocuparse em direcionar a construção de equipamentos e facilidades de forma adequada, evitando dessa forma, os efeitos negativos nos recursos, que os destroem ou reduzem sua atratividade". (Ruschmann, 1997) Nele deve constar o potencial da 
área a ser trabalhada, o nível de turismo desejado, a normatização da atividade e as maneiras de se chegar aos objetivos.

Por oferta turística podem-se entender produtos, bens ou serviços que um município ou localidade tem a oferecer para as pessoas que o visitam. Em função de sua estrutura, complexidade e heterogeneidade, a oferta turística resulta na composição de um conjunto de atividades, tanto econômicas como sociais e culturais. Ela compreende os atrativos em geral como recursos naturais, históricos e culturais; infra-estrutura em geral como meios de hospedagem; alimentação; transportes; entretenimento; serviços de apoio ao turista; e outros. A quantidade de bens e serviços consumidos pelos visitantes caracteriza-se demanda turística. Além da qualidade das destinações turísticas, da infra-estrutura oferecida ao visitante, a originalidade do lugar é freqüentemente avaliada. A essência do ecoturismo está em oferecer ao turista uma experiência rica e autêntica de vivência junto aos ecossistemas. Associados a isto, são propiciadas condições de conforto, aconchego e recreação, disponibilidade de equipamentos turísticos característicos e diferenciados, além do importante incentivo às práticas conservacionistas.

Freqüentemente, várias outras associações são feitas ao turismo ecológico em vista de uma estreita relação existente entre os princípios dessas atividades, em que são exemplos mais comuns os esportes de aventura; um turismo de cunho histórico-cultural, onde monumentos e velhas edificações constituem parte da oferta turística; o turismo de saúde e outros.

Em se tratando de ecoturismo, um importante segmento são os esportes radicais. Estes têm sido os grandes impulsionadores do ecoturismo no Brasil, e também no mundo. O trekking, o mountain-bike, as cavalgadas, a tirolesa, o cannoing, o floating, o rafting, o rappel e a pesca esportiva são algumas das diversas opções existentes. Seu desenvolvimento em sítios e fazendas pode auxiliar, além da geração de empregos, geração de renda, preservação da cultura e do ambiente, num problema comum de países subdesenvolvidos: o êxodo rural.

O Brasil é um país com vocação natural para o ecoturismo. Sua grande diversidade cultural e sua ampla extensão territorial propiciam uma oferta turística das mais variadas, fazendo com que o Brasil seja uma atração para os próprios 
brasileiros, permitindo ainda a prática da maioria das modalidades de turismo ecológico e também de esportes de aventura.

Mesmo após séculos de exploração predatória, os ecossistemas brasileiros guardam inúmeros e notáveis encantos, ainda praticamente inexplorados do ponto de vista do ecoturismo. Com iniciativa e estratégia dos agentes públicos e privados pode-se protegê-los, gerando emprego, renda e grande oportunidade de novos negócios.

Dia a dia, novas apostas no turismo ecológico surgem na tentativa de dinamizar pequenas comunidades. Todas as cinco regiões do país têm potencial suficiente para apostar no turismo ecológico e todas elas possuem pólos já consagrados. Mas, segundo um estudo da Embratur, a sinalização é insuficiente, e melhorias na infra-estrutura são desejáveis na grande maioria dos lugares. $O$ Poder Público ainda é um dos grandes responsáveis pelo impulso inicial que deve ser dado a essa, como a várias outras atividades, e também, um dos responsáveis pelos cuidados para que a atividade se perpetue.

O Ecoturismo é uma atividade que busca valorizar as premissas ambientais, sociais, culturais e econômicas conhecidas de todos, e inclui a interpretação ambiental como um fator importante durante a experiência turística. Os roteiros são elaborados através das agências operadoras, ou outras formas desenvolvidas pelo marketing, onde os consumidores irão desfrutar dos serviços de hotelaria, gastronomia, condutores, transportes, equipamentos, etc. Utilizarão ainda, a infra-estrutura básica da região (hospitais, farmácias, saneamento, coleta de lixo, posto de saúde, telefonia, etc.) adequada e ecologicamente corretas.

Se o ecoturismo no Brasil encontra-se em um estágio de desenvolvimento recente, este é o momento para que seja incentivada a introdução de uma política de âmbito nacional para o setor. Tal política deve orientar governos e legislativos para a implantação de suas estratégias de regulamentação e controle, assim como orientar agências de fomento para criar e facilitar o acesso a incentivos fiscais e financiamentos( Salvati, 2004).

Ressalta-se ainda, a importância do estímulo à qualificação profissional, a capacitação e aquisição de tecnologias apropriadas, a serem viabilizadas pelo empresariado. Existem empreendedores querendo investir, de forma séria, em ecoturismo com bons projetos, como aqueles, proprietários de área natural que 
transformam sua terra em RPPN, ficando obrigado, de forma perpétua, a conservar a propriedade.

Por isto é preciso implantar projetos bem embasados, dentro de uma política nacional integrada que aproxime o desenvolvimento do ecoturismo aos objetivos de sustentabilidade social, econômica e ambiental.

A falta de uma política nacional clara para o desenvolvimento do setor, aliada à forma desorganizada e, muitas vezes, irresponsável com que as pessoas tem praticado o ecoturismo, têm motivado uma série de preocupações aos governos locais, às organizações ambientalistas e às comunidades anfitriãs(Salvati, 2004).

\subsection{Marketing}

O Conceito de Marketing é bem diversificado, tendo como base a eterna procura de conseguir o melhor entrosamento possível entre segmentos da demanda e a oferta. Nesse processo, as empresas buscam permanentemente 0 melhor ajustamento entre os produtos que oferecem e algum grupo de consumidores no mercado.

Segundo Drucker apud Kotler (2000), marketing "é o processo do qual a economia é integrada à sociedade para servir às necessidades humanas". Por sua vez Levitt apud Kotler (2000), diz que "é o processo de atrair e manter o cliente", ao passo que Kotler (2000), o define como sendo "uma orientação da administração que visa proporcionar a satisfação do cliente e o bem-estar do consumidor em longo prazo, como forma de satisfazer aos objetivos e às responsabilidades da organização".

Estes autores variam suas definições, começando por um processo social, passando pela associação específica do processo de troca, até a visão de marketing como um instrumento gerencial. Isto mostra que o marketing, como objeto de estudos, é bem novo e que seus conceitos não tem definições claramente delimitadas, permitindo sempre novas e diferentes concepções.

Essa diferença de definição se dá pela dinâmica de mercado. Em virtude da acirrada concorrência, as empresas devem se ajustar a cada dia, para não serem ameaçadas de perderem suas posições e seus clientes. A dinâmica ocorre 
principalmente pelas mudanças a que o mercado está sujeito. Essas mudanças são:

\section{- Mudança no ambiente}

Essa mudança ocorre quando o ambiente em que o produto está inserido se altera, sem que a empresa esteja preparada; esse despreparo pode causar danos irreparáveis à vida do produto. Essas mudanças podem estar relacionadas com a economia, a política, a legislação etc. Exemplo: Aumento do dólar afasta os consumidores de pacotes internacionais.

\section{- Mudança no comportamento dos consumidores}

A mudança no comportamento do consumidor altera o jeito que o mesmo está acostumado a agir, mudando o entrosamento entre a oferta e a demanda. A alteração tem duas formas: a conjuntural, que desaparece quando a situação volta ao normal; e a de caráter estrutural, que é mais profunda e modifica os hábitos do consumidor, segundo suas atitudes, crenças e comportamentos. Exemplo: Conjuntural: Aumento do dólar motiva as viagens internas. Estrutural: Consciência ecológica, acabando com o turismo predatório.

\section{- Mudança na ação da concorrência}

A concorrência é um fator que pode decretar o fim de uma marca ou um produto. A ação competitiva força as empresas a sempre procurarem um NOVO AJUSTAMENTO. Esta ação pode consistir na entrada de novos concorrentes ou na saída de concorrentes atuais, no lançamento de novos produtos, na introdução de novas práticas gerenciais etc. Exemplo: Criação de parque temáticos mais modernos, transformando os já existentes em coisas do passado.

De acordo com Kotler (2000), marketing é um processo social por meio do qual pessoas e grupos de pessoas obtêm aquilo de que necessitam e o que desejam com a criação, oferta e livre negociação de produtos e serviços de valor com os outros. 
Quando se usa uma definição gerencial, o marketing é freqüentemente descrito como 'a arte de vender produtos'. Mas as pessoas se surpreendem quando ouvem que o mais importante em marketing não é vender! Vender é apenas a ponta do iceberg de marketing. Drucker apud Kotler (2000), expõe essa questão da seguinte maneira:

"pode-se presumir que sempre haverá necessidade de algum esforço de vendas, mas o objetivo do marketing é tornar a venda supérflua. A meta é conhecer e compreender tão bem o cliente que o produto ou o serviço se adapte a ele e se venda por si só. O ideal é que o marketing deixe o cliente pronto para comprar. A partir daí, basta tornar o produto ou o serviço disponível".

Por sua vez, a American Marketing Association apud Middleton (2002), oferece a seguinte definição:

Marketing (administração de) é o processo de planejar e executar a concepção, a determinação do preço (pricing), a promoção e a distribuição de idéias, bens e serviços para criar trocas que satisfaçam metas individuais $e$ organizacionais.

Segundo Zeithaml e Bitner (2003), lidar com esses processos requer uma quantidade considerável de trabalho e técnicas. A administração de marketing ocorre quando pelo menos uma das partes envolvidas em um processo de troca potencial pensa sobre os meios de obter as respostas desejadas das demais partes. A administração de marketing é vista como a arte e a ciência da escolha de mercados-alvo e da captação, manutenção e fidelização de clientes por meio da criação, da entrega e da comunicação de um valor superior para o cliente.

Um profissional de marketing é alguém que busca uma resposta (atenção, compra, voto, doação) de outra parte, denominada cliente potencial (prospect). Se duas partes estão buscando vender algo uma para a outra, ambas são denominadas profissionais de marketing.

Dessa forma o profissional de marketing precisa tentar compreender as necessidades do mercado-alvo, seus desejos e suas demandas. Necessidades 
descrevem exigências humanas básicas. As pessoas precisam de comida, ar, água, roupa e abrigo para poder sobreviver. Elas também tem uma necessidade muito grande de recreação, educação e entretenimento. Essas necessidades se tornam desejos quando são dirigidas a objetos específicos capazes de satisfazêlas. Um norte-americano necessita de comida, mas deseja um hambúrguer, batatas fritas e um refrigerante. Um habitante das Ilhas Maurício necessita de comida ,mas deseja uma manga, arroz, lentilhas e feijão. Desejos são moldados pela sociedade em que se vive.

Demandas são desejos por produtos específicos apoiados por uma possibilidade de pagar. Muitas pessoas desejam um Mercedes, mas apenas algumas podem e estão dispostas a comprar um. As empresas devem medir não apenas quantas pessoas desejam seu produto, mas também quantas efetivamente estão dispostas e aptas a adquiri-lo.

Apesar de muitas organizações ainda não terem adotado uma mentalidade de marketing, observando-se a acirrada competitividade encontrada no atual mundo globalizado, fica evidente que a sua utilização e incorporação tem sido um grande diferencial para as empresas que buscam o sucesso. Essas empresas estão vencendo a competição, atraindo e fidelizando clientes cada vez mais exigentes por produtos e serviços de extrema qualidade.

Hooley (2000) apresenta alguns princípios básicos de marketing que servem para guiar tanto o conceito como a ação do marketing.

Princípio 1 - O cliente é o centro de tudo

O primeiro princípio do marketing é o próprio conceito do marketing em si. Ele reconhece que os objetivos de longo prazo da organização sejam eles financeiros ou sociais, poderão ser mais facilmente alcançados se o cliente estiver extremamente satisfeito;

Princípio 2 - Os clientes não compram produtos

O segundo princípio fundamental estabelece que os clientes não compram produtos; eles compram o que o produto faz para eles. Em outras palavras, os 
clientes estão menos interessados nas características técnicas do produto ou serviço do que nos benefícios que eles obtêm por meio da compra, uso ou consumo do produto ou serviço;

Princípio 3 - O marketing é uma coisa importante demais para ser deixado a cargo apenas do departamento de marketing.

O marketing é uma tarefa de todos na organização. As ações de todos podem ter um impacto sobre os clientes finais e sobre sua satisfação.

Princípio 4 - Os mercados são heterogêneos

Torna-se mais evidente a cada dia que a maioria dos mercados não é homogênea, e sim constituída de clientes individuais diferentes, submercados ou segmentos. Enquanto alguns clientes compram um carro para se locomoverem a baixo custo de A para $B$, outros o farão porque desejam viajar de forma confortável ou segura; ao passo que outros, ainda o fazem por motivos de status ou para satisfazer e projetar sua auto-imagem. Os produtos e serviços que tentam satisfazer um mercado segmentado por meio de um produto padronizado geralmente fracassam ao tentar satisfazer diferentes tipos de clientes a um só tempo e se tornam vulneráveis a concorrentes, dispondo de metas mais objetivas.

Princípio 5 - Os mercados e clientes mudam constantemente

É um truísmo afirmar que a única coisa consistente é a mudança. Os mercados são dinâmicos e praticamente todos os produtos têm uma vida limitada até ser descoberta uma nova maneira de satisfazer o desejo ou a necessidade que os geraram; em outras palavras, até que apareça uma outra solução ou fornecedor do benefício.

Kotler (2000), afirma que marketing "consiste em determinar as necessidades e os desejos de mercados-alvo e em oferecer as satisfações desejadas de forma mais efetiva e eficiente que os concorrentes". 


\subsection{Marketing de serviços}

De maneira simplificada, serviços são ações, processos e atuações. Uma vez lançada uma definição simples e ampla para serviços, logo fica claro que os serviços não são produzidos apenas por empresas de serviços, mas também fazem parte daquilo que os fabricantes de bens manufaturados oferecem. Por exemplo, fabricantes de automóveis oferecem garantias e serviços de manutenção para seus automóveis; fabricantes de computadores oferecem garantias, contratos de manutenção e treinamento; fabricantes de equipamentos industriais oferecem serviços de entrega, administram o estoque e prestam serviços de manutenção. Todos esses serviços são exemplos de ações, processos e atuações.

Embora se esteja trabalhando com uma definição simples e ampla para os serviços, é preciso ter consciência de que, ao longo do tempo, os serviços e o setor de serviços como um todo foram definidos de várias formas sutilmente diferentes. A variedade de definições muitas vezes pode explicar a confusão ou os desacordos entre as pessoas ao discutirem os serviços ou quando descrevem indústrias inseridas no setor da economia designado como setor de serviços. É compatível com a simples e ampla definição que afirma que os serviços "incluem todas as atividades econômicas cujo produto não é uma construção ou produto físico, é geralmente consumido no momento em que é produzido e proporciona valor agregado em formas (como conveniência, entretenimento, oportunidade, conforto ou saúde) que são essencialmente intangíveis, de seu comprador direto". (Cobra, 2001)

À medida que se inicia a discussão acerca do marketing e da administração de serviços, é importante fazer a distinção entre serviços e serviço ao cliente. Serviços como amplamente definido aqui, abrange uma ampla gama de indústrias. As seguintes empresas são consideradas empresas de serviços: AT\&T (telecomunicações), Marriot International (hotéis), American Airlines (transportes), Bank One (serviços financeiros). No entanto, os serviços podem ser oferecidos ao mercado tanto por fabricantes quanto por empresas de tecnologia. A IBM e a Compaq (tradicionalmente consideradas fabricantes) oferecem serviços de consultoria em tecnologia da informação (TI) ao mercado, competindo com a Andersen Consulting, uma empresa tradicional do setor de serviços. O serviço ao 
cliente também é prestado por todos os tipos de empresas - fabricantes, empresas de $\mathrm{TI}$, empresas de serviços. Serviço ao cliente é o serviço prestado para dar apoio ao grupo de produtos principais de uma empresa.

De acordo com Zeithaml e Bitner (2003), há consenso geral de que existem diferenças inerentes entre bens e serviços e de que as mesmas resultam em desafios exclusivos, ou ao menos diferentes, para a administração de serviços e para os fabricantes que fazem dos serviços parte importante de sua oferta central. Tais diferenças e as implicações de marketing associadas aos serviços são a intangibilidade, a heterogeneidade, a produção e consumo simultâneos e a perecibilidade.

- a intangibilidade - um serviço é mais intangível do que tangível. Vendem-se sonhos, fantasias, sensações. E, o grande desafio do homem de marketing é tornar tangível esses aspectos intangíveis de um serviço destacando os benefícios de uma forma clara.

- A produção e consumo simultâneos - muitos serviços não podem ser produzidos sem a presença e cooperação do cliente. Como os serviços não podem ser armazenados eles devem ser produzidos ao mesmo tempo em que são consumidos.

- a perecibilidade - quando um serviço exige a presença de um cliente, para receber e consumir o serviço, a empresa do setor de serviços deve estar atenta ao tempo do cliente, pois os serviços são perecíveis. Eles não podem ser armazenados para consumo posterior. A demanda de serviços deve ser bem calculada e administrada.

- A inseparabilidade - o serviço depende da performance, sobretudo de pessoas. Um funcionário é parte essencial de um serviço. E, como decorrência disso, o setor de serviços é quase sempre caracterizado como de mão-de-obra intensiva. 
A qualidade do serviço no produto turístico é essencial para sua sobrevivência. O serviço é uma atividade ou benefício, essencialmente intangível, em que um oferece e outro recebe, não resultado na posse de produto algum. Quando se aluga um quarto de hotel ou se voa de avião, tem-se o direito de utilizá-los por apenas alguns momentos, que ao término do serviço, não se tem a sua posse.

\subsubsection{As ferramentas de comunicação: enfoque promocional}

As técnicas promocionais são utilizadas para fazer com que clientes potenciais conheçam os produtos, estimular a demanda e geralmente oferecer incentivos para compra.

Conforme tratado por Cobra (2001), o produto turístico é composto por um conjunto de bens e serviços com características diferenciadas e que apresenta como aspecto mais destacado a intangibilidade.

Entendido como um bem de consumo abstrato, diferentemente dos bens tangíveis que podem ser apreciados e avaliados pelos seus detalhes concretos cor, peso, formato - o produto turístico é apresentado ao futuro consumidor de uma forma diferenciada. Por meio de fotos e descrições o fornecedor tenta estimular e induzir o cliente.

A promoção implica na adequação do conteúdo da mensagem e da mídia em relação ao público-alvo, considerando o estilo de vida, gostos, nível educacional, preferências, etc.

Algumas ações promocionais buscam particularmente "apresentar" a empresa, o produto, o serviço. Procuram destacar e elevar sua marca, sua imagem e proporcionar força de vendas. Uma dessas ações é o patrocínio. Segundo Malagodi e Cesnik (1999) "a relação de patrocínio é um negócio". De acordo com essa consideração, esse negócio deve proporcionar benefícios para ambos os lados - patrocinadores e patrocinados. O retorno obtido pela empresa diferenciará custo de investimento.

Ainda segundo Malagodi e Cesnik (1999), é importante salientar que o patrocínio deve satisfazer às seguintes condições: 
- atingir o público-alvo desejado;

- divulgar a marca do patrocinador;

- promover seus produtos;

- potencializar as vendas;

- contribuir para a expansão e conquista de novos mercados.

Mercados de massa se fracionam em nichos de mercado. Os consumidores, cada vez mais exigentes, apresentam demandas individualizadas. Os empreendimentos precisam estar preparados para atender essas individualidades e a promoção deve estar alinhada com os propósitos e comportamento desses novos consumidores.

Em geral as empresas buscam atender as demandas dos consumidores, mas também necessitam contar com sua capacidade de provocar essas demandas. Carece persuadir o consumidor a experimentar seus produtos. $\mathrm{O}$ próprio conceito de marketing principalmente quando se fala em promoção sugere provocar o consumidor despertando-o para novos desejos e necessidades.

Dentro desse contexto a comunicação é o momento da sedução que visa empolgar o cliente a comprar o serviço. Ela precisa ser objetiva, falar com clareza dos principais pontos da oferta e dar oportunidade para que o consumidor fantasie a oferta, sentindo-se envolvido e comprometido com ela. (Cobra, 2001).

Percebe-se que a publicidade é a ferramenta clássica de comunicação usada pelos departamentos de marketing das empresas, como parte das campanhas de marketing, para desenvolver consciência, compreensão, interesse e motivação entre um público-alvo. De particular importância no turismo, o mix de comunicações mais amplo também inclui promoções de vendas, relações públicas, merchandising, venda pessoal, informações impressas e eletrônicas. Assim, a função do marketing é coordenar todos os elementos sob o controle da organização a fim de lançar mensagens consistentes que otimizam o posicionamento escolhido.

A publicidade, muito embora seja um assunto bastante técnico quanto a sua implementação, suas funções essenciais são fáceis de se compreender. É de fácil 
assimilação pelo público consumidor e apresenta-se como um dos principais meios de manipulação da demanda e de influência sobre o comportamento dos consumidores. (Middleton, 2002).

Tão logo o público seja identificado pelo anunciante, o processo de influenciar e atingir é relativamente direto. Mas, é importante estar atento ao planejamento das mensagens para que estas sejam facilmente recebidas e, sobretudo, compreendidas.

Uma definição de publicidade dada pela Associação de Marketing Americana e apresentada por Middleton (2002), é: "qualquer forma paga de apresentação não-pessoal e promoção de idéias, bens ou serviços a um público por parte de um patrocinador identificado".

Como assunto técnico, a publicidade possui terminologia própria. A tabela a seguir apresenta dezoito termos mais utilizados no meio publicitário.

\begin{tabular}{|c|c|}
\hline Público & $\begin{array}{l}\text { Usado de forma genérica para descrever leitores, } \\
\text { espectadores, ouvintes expostos a todas as formas de mídia. } \\
\text { "Público-alvo" descreve os segmentos identificados para fins } \\
\text { de comunicação. }\end{array}$ \\
\hline Cópia & $\begin{array}{l}\text { As palavras incluídas em uma propaganda, normalmente com } \\
\text { três componentes: um "título" para chamar a atenção, o } \\
\text { "corpo" para apresentar a informação, e uma "linha final" para } \\
\text { concluir ou aprovar. }\end{array}$ \\
\hline Cobertura & A proporção do público-alvo atingida pela propaganda. \\
\hline CPT & $\begin{array}{l}\text { Sigla do inglês "custo por mil" do grupo-alvo ao qual qualquer } \\
\text { propaganda é exposta. O custo por mil é um número de custo } \\
\text { básico usado para a compra de espaço na mídia. Como o } \\
\text { nome sugere, se refere ao custo médio de atingir } 100 \\
\text { pessoas de público-alvo, e é útil para comparações em tipos } \\
\text { de mídia e veículos diferentes. }\end{array}$ \\
\hline Execução criativa & $\begin{array}{l}\text { A opção de temas atrativos, idéias, figuras, situações, } \\
\text { símbolos e palavras usadas para comunicar a mensagem } \\
\text { desejada. }\end{array}$ \\
\hline Resposta direta & Propaganda através da qual a resposta do público proposto é \\
\hline
\end{tabular}




\begin{tabular}{|c|c|}
\hline & $\begin{array}{l}\text { um contato direto com o produtor por telefone, carta, cupom } \\
\text { ou Internet, sem passar por um canal de distribuição. }\end{array}$ \\
\hline Questão editorial & $\begin{array}{l}\text { O conteúdo da mídia, que não seja a propaganda, controlado } \\
\text { por políticas editoriais. }\end{array}$ \\
\hline Taxas e comissões & $\begin{array}{l}\text { Tradicionalmente, as agências de publicidade ganhavam sua } \\
\text { renda através de comissões pagas sobre a compra de } \\
\text { espaço na mídia. Atualmente, as estruturas de pagamento } \\
\text { variam através de atividades pagas por meio de taxas e/ou } \\
\text { resultados obtidos juntamente com pagamentos baseados } \\
\text { em comissões. }\end{array}$ \\
\hline Freqüência & $\begin{array}{l}\text { O número de vezes que uma propaganda é colocada ou } \\
\text { inserida em um período de tempo específico. Uma estratégia } \\
\text { do tipo 'explosiva' concentra as propagandas em um curto } \\
\text { período, e uma estratégia 'em doses homeopáticas' mostra } \\
\text { as propagandas por um longo período de tempo. }\end{array}$ \\
\hline Inserção & $\begin{array}{l}\text { Uma aparição de uma propaganda. Os compradores de mídia } \\
\text { geralmente compram uma série de inserções e não uma } \\
\text { única. }\end{array}$ \\
\hline Mídia & $\begin{array}{l}\text { Jornais, televisão, rádio e outros meios de comunicação de } \\
\text { circulação em massa para levar mensagens, pagas ou não, } \\
\text { às pessoas. A mídia de publicidade é aquela que vende } \\
\text { espaço para os anunciantes como uma transação comercial. }\end{array}$ \\
\hline Veículo de mídia & $\begin{array}{l}\text { Títulos individuais da mídia. Como The Times, Newsweek, } \\
\text { Vogue etc. }\end{array}$ \\
\hline OTS & $\begin{array}{l}\text { Sigla do inglês "oportunidades para serem vistas" ou } \\
\text { oportunidades do público-alvo de ver qualquer propaganda } \\
\text { em particular. É uma função de cobertura e freqüência } \\
\text { (cobertura x freqüência). }\end{array}$ \\
\hline Posição & $\begin{array}{l}\text { O local em que a propaganda é exibida, ou seja, capa da } \\
\text { frente, na parte de dentro da capa da frente/trás, páginas da } \\
\text { direita/esquerda, parte superior/inferior etc. Os custos da } \\
\text { mídia variam com a qualidade da posição. }\end{array}$ \\
\hline
\end{tabular}




\begin{tabular}{|l|l|}
\hline Proposição & $\begin{array}{l}\text { A mensagem clara e simples de uma propaganda, } \\
\text { geralmente centralizada no motivo da compra do produto, ou } \\
\text { seja, o principal benefício. }\end{array}$ \\
\hline Tabelas de tarifas & $\begin{array}{l}\text { Os preços publicados para o espaço publicitário produzido } \\
\text { pelo veículo da mídia em questão. As agências recebem } \\
\text { descontos sobre os preços publicados, que era parte do } \\
\text { sistema baseado em comissões. }\end{array}$ \\
\hline Parcela de voz & $\begin{array}{l}\text { Compara o gasto da propaganda de uma organização ao } \\
\text { gasto total do mercado em propaganda. } \\
\text { USP }\end{array}$ \\
$\begin{array}{l}\text { Sigla do inglês "proposição única de venda" - um produto } \\
\text { particular ou característico da organização que a distingue da } \\
\text { concorrência e é um grande motivo para compra. }\end{array}$ \\
\hline
\end{tabular}

Fonte: Middleton (2002)

\section{A seleção do veículo}

A seleção dos tipos, veículos ou mesmo peças de mídia dependem em grande parte das características e hábitos do mercado consumidor. A empresa selecionará os veículos de acordo com o perfil do mercado a ser atingido. Por exemplo, uma revista ou jornal que aborda assuntos diversos, caracteriza-se como um meio de comunicação sem uma segmentação específica, ou seja, um veículo de massa. Já o veículo direcionado tem um público certo, por exemplo, uma revista que trata somente de gastronomia tem seu público definido.

Uma outra questão na escolha ou seleção do tipo de mídia é os custos de produção e inserção. Pode-se analisar, como exemplo, os custos de produção e inserção da mídia eletrônica que é tida geralmente como uma forma cara. Para um pequeno empreendimento seria, então, um obstáculo à utilização desse meio de comunicação. No entanto, é possível buscar alternativa viável, como a possibilidade de uma propaganda compartilhada ou cooperada, que consiste na divisão de custos entre grupo de participantes (Kuazaqui, 2002). 


\section{Marketing mix}

As organizações de turismo precisam estar atentas às características e também as mudanças no perfil do consumidor, procurando manipular seu produto, preço, ponto de venda e promoção para conquistar e manter o cliente. Percebese, portanto, a necessidade - tanto para grandes organizações como para pequenos empreendimentos - dentre outras ações, de manter-se um banco de dados atualizado com elementos que os orientem quanto ao comportamento do cliente e tendências de consumo.

Assim, identificando-se as necessidades atuais e tendências de consumo, entende-se ser possível formatar e oferecer produtos e serviços turísticos diferenciados. Porém, tão ou mais importante que disponibilizar esses produtos e serviços é a utilização de técnicas promocionais e mídias publicitárias que cumpram o objetivo de despertar os consumidores para a aquisição e consumo dos produtos turísticos.

Aqui, é importante mencionar Swarbrooke e Horner (2002) que destacam a necessidade de dados de pesquisa para auxiliar a indústria do turismo no que tange a:

- identificar oportunidades para o desenvolvimento de produtos;

- estabelecer preços em relação aos praticados pela concorrência e ao que os consumidores estiverem dispostos a pagar;

- assegurar que a rede de distribuição esteja funcionando de maneira eficiente;

- selecionar a melhor combinação de técnicas promocionais e a mídia publicitária mais adequada;

- subdividir o mercado total em segmentos para os quais a empresa possa direcionar seus esforços;

- ajustar a prestação de serviços de acordo com as observações dos clientes;

- revisar e mudar marcas e logotipos;

- tomar decisões sobre investimentos em novas instalações; 
- escolher locações para novos hotéis e parques temáticos, por exemplo;

- sugerir oportunidades para diversificação

É senso comum que o segmento turístico de um modo geral e, particularmente os empreendimentos ecoturísticos, experimentarão cada vez mais um ambiente de acirrada concorrência. Terão de adaptar-se a uma situação de máxima competitividade com a oferta crescente de novos atrativos, mais serviços turísticos, para uma demanda cada vez mais exigente e segmentada. O marketing deve atuar eficazmente nas organizações para prover respostas a esse cenário competitivo.

Ainda segundo Kotler (2000), o mix de marketing é a mistura de variáveis de marketing controláveis que a empresa utiliza para atingir o nível desejado das vendas ao mercado-alvo.

Esse conjunto de variáveis - conhecido como 4 P's de marketing (produto, preço, promoção, praça) - oferece ao gerente de marketing subsídios para a tomada de decisões. Entende-se como 4 P's o conjunto de ferramentas que a empresa utiliza para perseguir seus objetivos de marketing no mercado-alvo.

\subsection{Marketing turístico}

O turismo é o maior dos movimentos da história da humanidade e se caracteriza por sua taxa de crescimento constante. Ele responde a uma série de necessidades humanas: de espaço, movimento, bem-estar, expansão e repouso, longe das tarefas impostas pelo trabalho cotidiano ou rotina. Hoje o turismo não é privilégio de algumas classes. Trata-se de um movimento "sem classes", que graças à política dos "pacotes turísticos", proporciona a possibilidade de viajar a quase todas as pessoas dos países industrializados, tornando-se, cada vez mais, uma reivindicação e um direito do homem civilizado.

O Marketing turístico é segundo Krippendorf (2003):

"a adaptação sistemática e coordenada da política das empresas de turismo, tanto privadas como do Estado, no 
plano local, regional, nacional e internacional, visando à satisfação das necessidades de determinados grupos de consumidores, obtendo, com isso, um lucro apropriado".

Krippendorf (2003), é o estudioso que primeiro desenvolveu e lançou os fundamentos do marketing turístico, que embora acompanhem os conceitos do marketing tradicional (bens tangíveis), se baseou nas singularidades do produto, que se originaram na sua intangibilidade.

Ele é dividido em duas faces distintas: o turismo emissivo e o receptivo. A aplicação das técnicas de mercado pelas operadoras de turismo, é conhecida como "turismo emissivo", onde apoiado por dados estatísticos a respeito de seus clientes elabora produtos compatíveis para a venda, chamados "pacotes turísticos" com destinos a centros de ecoturismo, de cultura, de estudos, de negócios entre outros. A função dessas operadoras é de planejar produtos dando aos seus clientes várias opções de destinações, dentro de um mesmo tipo, tentando assim conseguir a atenção do turista em potencial e por conseguinte a sua venda.

Já o "turismo receptivo" se refere aos locais que serão visitados pelos turistas. A localidade que se destina ao turismo deve estar preparada para essas visitas, mantendo o mínimo de infra-estrutura. O principal agente deste tipo de turismo é o Estado, que por ser "proprietário" da destinação tem de dar as condições básicas, como estradas, saúde, legislação e outras formas de preservar e atender os visitantes. Também fazem parte deste rol as empresas e entidades particulares que trabalham dando condições de hospedagem, transporte, alimentação etc.

A ênfase no mercado está sempre presente nas definições sobre marketing, seu objetivo é identificar as necessidades e desejos dos consumidores. De fato, o conhecimento do mercado constitui requisito indispensável para o sucesso do processo de troca entre as organizações e os consumidores.

Porém, ao nível da concepção, o produto turístico - destino - não pode ser apenas determinado pelas necessidades e desejos dos consumidores. Duas restrições podem ser apontadas: 
- Inexistência de recursos primários - em muitas situações a satisfação das necessidades e desejos dos consumidores depende de recursos primários que, em alguns casos, não são susceptíveis de criação pelo Homem (ex: geografia, clima,...), enquanto em outros a ação do Homem nunca se refletirá no curto prazo (ex: patrimônio histórico, patrimônio cultural,...).

- Interesses da comunidade local - não obstante as indiscutíveis vantagens econômicas do turismo, pela criação da riqueza que proporciona aos residentes dos destinos, este pode, em alguns casos, gerar impactos sociais e ambientais negativos que conduzam à sua rejeição (massificação desordenada, vandalismo,...). Importa ter presente que o layout da "fábrica do turismo" não se circunscreve a "X" metros quadrados, abrangendo comunidades locais na sua plenitude.

Segundo Beni (2001), marketing de turismo pode ser definido como um processo administrativo através do qual as empresas e outras organizações de turismo identificam seus clientes (turistas), reais e potenciais, e com eles se comunicam para conhecerem e influenciarem suas necessidades, desejos e motivações nos planos local, regional, nacional e internacional em que atuam, com o objetivo de formular e adaptar seus produtos para alcançar a satisfação ótima da demanda.

$\mathrm{E}$, mais que isso, o marketing busca despertar desejos e necessidades nos consumidores e clientes e garantir a plena satisfação desses sentimentos através da apresentação de produtos e serviços de qualidade superior, num processo de troca, cujo resultado deverá motivar o fornecedor ao desenvolvimento de novos produtos e serviços.

\subsection{Produto turístico}

Compondo o produto turístico, tem-se uma gama de serviços em que como ocorre na maior parte das atividades pertencentes ao setor terciário - a produção e o consumo são processos simultâneos e "resultados de uma série de combinações de serviços efetuados pelas empresas especializadas no 
atendimento das necessidades dos viajantes desde que saem até que regressam as suas casas". (Boullon, 1998)

O produto turístico é o conjunto de bens e serviços que se oferecem ao mercado para um conforto material e espiritual do turista. (Tabares, 1998). Porém, não se deve confundir matéria-prima com produto turístico. Por exemplo: 0 Parque Nacional da Chapada dos Veadeiros é matéria prima, rica e diversificada, mas é necessário transformá-lo em "um produto que tenha preço justo, qualidade de serviços, criatividade, identidade e principalmente diferenciais agregados". (Carvalho, 2000)

Outra questão relevante a ser considerada no desenvolvimento do turismo de uma região é a elaboração de um plano de marketing, ou seja, o "processo de planejamento e execução desde a concepção, apreçamento, promoção e distribuição de idéias, mercadorias e serviços para criar trocas que satisfaçam os objetivos individuais e organizacionais". (Cobra, 1992)

Neste processo o marketing considera quatro conceitos básicos:

- Produto - é a oferta de objetos, serviços, atendimento, bens, sempre no sentido de satisfazer os clientes, no setor turístico especificamente produto é a "materialização de uma solução mercadológica para atender necessidades e desejos de turistas ou integrantes do mercado turístico", (Giacomini, 2001)

- Preço - o preço em serviços turísticos esta diretamente ligado ao tipo de clientela que se deseja atingir, ou seja "é a ferramenta importante também para definir o nível de status desejado para o serviço a ser vendido", (Mielenhausen, 2000)

- Ponto - ou praça e corresponde á disponibilização, distribuição ou acesso do turista ás estruturas ofertadas, (Giacomini, 2001)

- Promoção - é a atividade de comunicação dirigida diretamente ao potencial interessado, e normalmente associado á atividade de vendas, com o principal objetivo de "aproximar o produto/serviço o máximo possível do cliente". (Mielenhausen, 2000) 
No caso de marketing ecológico pode-se falar de um quinto $p$, de Preservação, que destaca a construção e preservação de uma imagem de ecologicamente correto à instituição e aos produtos.

O marketing ecológico consiste, portanto, na prática de todas aquelas atividades inerentes ao marketing, porém, incorporando a preocupação ambiental e contribuindo para a conscientização ambiental por parte do mercado consumidor.

Ao adotar o marketing ecológico, a organização deve informar a seus consumidores acerca das vantagens de se adquirir produtos e serviços ambientalmente responsáveis, de forma a estimular e despertar o desejo do mercado por esta categoria de produtos.

O marketing é uma técnica de gestão, não de comunicação como muitos pensam. Empresas orientadas para o marketing entendem que seu objetivo é descobrir as necessidades e desejos das pessoas e satisfazê-los com maior eficiência que seus concorrentes. (Cobra, 1992)

Avaliando o produto turístico com base na teoria geral dos sistemas segundo Petrocchi (1998), é possível classificá-lo como um sistema aberto, ou seja, interage com o meio externo de forma dinâmica, recebe constantes entradas - material, energia e informações.

Os subsistemas, processos internos, interagem entre seus componentes e influenciam o desempenho do todo. Os principais subsistemas do turismo são "hospedagem, meio ambiente, gestão governamental, equipamentos, formação profissional, promoção e informações, viário, transporte e comunicação". (Petrocchi, 1998)

Para que esta interação ocorra de forma contínua, o processo de transformação, a exploração dos recursos, a direção dos investimentos, a orientação da evolução tecnológica e a mudança institucional devem ser harmônicas e reforçar o potencial presente e futuro, a fim de atender às necessidades e aspirações humanas, ou seja, o turismo sustentável.

Para que o turismo seja sustentável, sua expansão deve ocorrer até o limite da capacidade territorial de receber visitantes. A preservação do meio ambiente 
depende dos limites impostos ao crescimento do turismo, tanto do ponto de vista físico como social.

É de competência do gestor público do turismo, preocupar-se com a expansão da urbanização, com o ordenamento do crescimento, com a infraestrutura, com a segurança pública e com os serviços locais, além de outros fatores que influenciem diretamente na qualidade de vida da comunidade local e do turista em estadia. (Petrocchi, 1998).

Este gestor público deverá definir a política do turismo, com base em um planejamento macro envolvendo os diversos segmentos da sociedade organizada local, desmembrados em projetos e programas que poderão ser reprogramados estrategicamente visando garantir a sustentabilidade turística e do meio ambiente em que está inserido. (Petrocchi, 1998).

Neste processo de definição da política do turismo o envolvimento da sociedade organizada é de fundamental importância. Por sociedade organizada entende-se, "o agrupamento de indivíduos entre os quais se estabelecem relações econômicas, políticas e culturais". (Petrocchi, 1998)

\section{Metodologia}

Este trabalho é fundamentado em uma pesquisa exploratória realizada no contexto histórico-social no qual se desenvolve o turismo no Distrito Federal. A pesquisa qualitativa/exploratória foi realizada com o objetivo de observar, registrar e sistematizar os dados coletados, possibilitando, desta forma, uma aproximação maior da realidade local e uma investigação das questões relacionadas ao assunto.

Nesta pesquisa obtiveram-se os dados descritos sobre as pessoas, lugares e processos interativos através do contato direto do pesquisador com a situação estudada, neste caso, alguns agentes diretamente responsáveis pelos empreendimentos enfocados no trabalho.

A coleta dos dados secundários ocorreu em fontes bibliográficas e documentais, como: livros, artigos, estudos teóricos, revistas científicas e publicações governamentais, bem como através da Internet. 
A coleta dos dados primários foi efetuada através da aplicação de questionários semi-estruturados, com perguntas direcionadas aos dirigentes dos empreendimentos, tendo como objetivo levantar informações sobre o turismo local junto aos empresários, utilizando a própria fala dos entrevistados como suporte para interpretação da pesquisa.

Com base nas informações coletadas foi possível chegar a algumas conclusões que possam exemplificar o panorama da atividade nos empreendimentos estudados, bem como permitiu identificar algumas ações a serem implementadas visando ao desenvolvimento de ferramentas de marketing na promoção de tais empreendimentos.

\section{Universo da pesquisa}

A pesquisa foi desenvolvida em dois empreendimentos situados no entorno de Brasília e que oferecem atividades ecoturísticas. O primeiro visitado foi a Área de Proteção Ambiental - APA denominada Chapada Imperial. E em seguida um empreendimento que se apresenta também como "Museu Rural" e que oferece atividades de lazer e pedagógicas, denominado Hotel-fazenda Velha.

\section{Chapada Imperial}

Desde 1985, a Chapada Imperial vem sendo preservada tornando-se hoje a maior unidade de mata particular do DF. Localizada na APA de Cafuringa, encontra-se no ponto mais alto do DF, sendo cortada pelo Ribeirão Dois Irmãos que nasce em suas terras e percorre $10 \mathrm{~km}$, num desnível acima de $500 \mathrm{~m}$, a possuindo diversas cachoeiras e piscinas naturais de águas cristalinas. São mais de 20 pontos visitáveis, em uma extensão de $5 \mathrm{~km}$, com várias trilhas diferenciadas pelo grau de dificuldade.

Trabalha com Educação Ambiental, buscando a conscientização através da conservação e preservação do ecossistema. Utilizando mão-de-obra local, comercializa produtos regionais: queijos, doces, salgados, artesanato, etc. 
A Chapada Imperial dispõe de um pequeno centro de recepção e um restaurante com mesas rústicas onde oferece práticos típicos da região. As atividades desenvolvidas são: caminhadas, trekking, rappel, mountain bike, arvorismo, sendo que ainda recebe grupos de estudantes e profissionais para treinamento e lazer.

A listagem a seguir apresenta algumas das instituições visitantes: Faculdade da Terra de Brasília-FTB; Faculdade UPIS; CEUB; UnB; Centro de Excelência em Turismo-UnB; Faculdade Euro Americana; ICESP; Faculdade Caiçaras; Colégio Mackenzie; Colégio das Nações; Colégio Leonardo da Vinci; Colégio AD1; Polícia Civil do Distrito Federal ; Corpo de Bombeiros do Distrito Federal; IBAMA; SEBRAE-DF.

\section{Fazenda Velha}

A Fazenda Velha encontra-se na Chapada da Contagem na região rural administrativa de Sobradinho-DF. Banhada pelo Ribeirão Sobradinho possui pequenas trilhas interpretativas nas quais os visitantes poderão desfrutar de informações sobre o meio ambiente, a hidrografia e o bioma do cerrado.

A casa sede da Fazenda Velha data de 1884 e foi restaurada obedecendo aos padrões da época por Roeland Emiel Steylaerts, membro do Instituto Maurício de Nassau. Construção do século XVIII, em estilo colonial, depois de restaurada passou a se constituir em museu, expondo objetos e utensílios de época. Composto por construções e equipamentos que remontam os hábitos das antigas fazendas da região, constitui um verdadeiro Cenário Histórico-cultural. Pode-se encontrar carro de boi, charrete, engenho, casa de rapadura, monjolo, casa de farinha, capela. Também possui um restaurante com boa estrutura onde são servidas comidas típicas.

Uma estrutura de lazer foi montada nas proximidades da casa-sede e compreende o lago, lanchonete, piscina, toboágua, quadra esportiva e parque infantil. Mantém ainda um grande salão disponível para treinamento de pessoal

Oferece um Programa de Integração História, Cultura e Lazer - um conjunto de atividades pedagógicas e recreativas destinadas a estudantes do $1^{\circ}$ 
grau. Também recebe grupos para reuniões de trabalho, workshop, confraternizações e eventos em geral.

\section{Apresentação e análise}

Com base na pesquisa, implementada através de visitas aos locais e a aplicação de um questionário de entrevista onde os entrevistados foram os próprios proprietários, foi possível apresentar a análise que segue. As variáveis foram divididas nos seguintes grupos:

- Identificação do empreendimento

- Sazonalidade

- Cliente

- Mercado

- Promoção/divulgação

O primeiro grupo de perguntas tratou da identificação do empreendimento. Quanto à localização, ambos estão situados a uma distancia aproximada de 50 km do ponto central de Brasília (estação rodoviária). O único meio de acesso é o rodoviário, com utilização de carros particulares, vez que não existe linha de transporte regular de concessão pública. As estradas são pavimentadas na maior distância e complementadas em pequeno trecho de terraplenagem, e se encontram tem boas condições de tráfego. Podem ser acessadas por quaisquer tipos de veículos: veículos leves, vans, trailers, micro-ônibus e ônibus. Quanto ao tempo de existência os dois empreendimentos têm entre 5 e 10 anos de atividades.

Considerando-se a sazonalidade da demanda turística e as estratégias promocionais dos empreendimentos para esse período, constatou-se que:

- A APA Chapara Imperial considera o seguinte quadro sazonal.

\begin{tabular}{|l|l|l|l|l|l|l|l|l|l|l|l|}
\hline JAN & FEV & MAR & ABR & MAI & JUN & JUL & AGO & SET & OUT & NOV & DEZ \\
\hline B & B & B & M & M & M & M & A & A & M & B & B \\
\hline
\end{tabular}


Legenda: A-alta estação; M-média estação; B-baixa estação; T-todas

- O Hotel-Fazenda Velha apresenta como sazonalidade o quadro abaixo.

\begin{tabular}{|l|l|l|l|l|l|l|l|l|l|l|l|}
\hline JAN & FEV & MAR & ABR & MAI & JUN & JUL & AGO & SET & OUT & NOV & DEZ \\
\hline B & B & B & M & A & A & A & A & M & M & M & A \\
\hline
\end{tabular}

Legenda: A-alta estação; M-média estação; B-baixa estação; T-todas

Observa-se, pois, que o primeiro experimenta um maior período - 5 meses - de baixa estação enquanto o segundo considera apenas 3 meses de baixa temporada. No entanto, ambos definem suas ocupações com a seguinte taxa média:

- $\quad$ alta $=80 \%$

- média $=50 \%$

- baixa $=10 \%$

Questionados sobre o que fazer para reduzir a sazonalidade, obteve-se a seguintes respostas: para a Chapada Imperial, efetuar mais propaganda e divulgação. Já para a Fazenda Velha, diversificar a clientela e implantar turismo de eventos será a saída. Ambos acrescentaram que montam pacotes específicos para a baixa estação.

O proprietário da Chapada Imperial fez comentários sobre a falta de incentivos governamentais ao fomento do turismo na região, especialmente na baixa temporada. "É, também, responsabilidade do Estado fornecer incentivos aos empreendimentos ecoturísticos, posto que, estes retornam pela arrecadação de impostos e geração de postos de trabalho. A Chapada justifica o longo período de baixa temporada ( novembro a março ) em função de ser o período mais chuvoso no DF e suas atividades estarem condicionadas à condição de tempo bom. Já a Fazenda Velha considera os meses de novembro e dezembro - apesar das chuvas - ainda meses de média e alta temporada justificando sua posição no mercado a possibilidade de ofertar produtos alternativos. Por exemplo: a cessão 
de espaços para a realização de festas de confraternização de empresas e entidades diversas. Também disponibiliza local para treinamento de pessoal.

O forte calor dos meses de agosto e setembro atrai muitos turistas para a visitação das cachoeiras; as trilhas apresentam melhores condições de uso, portanto os meses de agosto e setembro são considerados a melhor época para visitar a Chapada imperial, comentou o entrevistado.

No terceiro quadro ambos demonstraram preocupação com a satisfação do cliente, respondendo que fazem pesquisa com periodicidade mensal para conhecer o perfil dos turistas e oferecer produtos com qualidade, destacando a hospitalidade como atrativo dos empreendimentos.

O quarto grupo discutiu sobre o mercado. As respostas fornecidas pelos entrevistados demonstraram que ambos atingem os mercados regional, nacional e internacional e atendem basicamente a um público específico composto por famílias e estudantes. Outro ponto em comum refere-se à questão da formação de preços, onde os entrevistados foram unânimes em afirmar que determinam os preços dos produtos turísticos levando em consideração os custos de produção e atentando para os períodos de maior ou menor demanda. Outra uniformidade percebida foi quando se questionou a forma de comercialização. As respostas foram as mesmas: venda direta. Nenhum dos dois empreendimentos utiliza as operadoras para fomentar suas vendas.

Discutindo-se as formas de promoção e divulgação dos produtos, os principais aspectos foram assim analisados. Os dois empreendimentos não dispõem de uma assessoria de marketing para direcionar suas ações promocionais. Atividades estas desenvolvidas pelos próprios administradores.

Quando ao investimento na promoção, a Chapada Imperial disponibiliza entre $6 \%$ a $10 \%$ do faturamento enquanto a Fazenda Velha investe entre 0 e $5 \%$ para promover seus produtos.

A razão para tão baixo percentual investido na promoção da Fazenda Velha foi explicada pela entrevistada com a seguinte frase: "Por ser uma área de turismo rural, tendo como grande atrativo a história, a cultura e a preservação do 
patrimônio, muitas vezes nossa divulgação é feita por matérias em diversos meio s de comunicação veiculadas na mídia espontânea".

Também coincidem as repostas quando perguntados aonde são veiculadas as ações promocionais. A resposta única foi: no DF. E sobre o objetivo das ações promocionais: aumentar a demanda em geral.

A pesquisa mostrou que na Fazenda Velha a divulgação é feita somente pela administração e basicamente com verba própria, enquanto que, a Chapada Imperial tem o apoio do Sindicado de Turismo Rural e Ecológico do DF e a faz em conjunto com outros empreendimentos dividindo os custos.

Mais uma vez os dois têm o mesmo entendimento e, apontam o elevado custo de veiculação nos meios de comunicação como o principal problema enfrentado para a divulgação dos produtos e serviços. Os meios utilizados pelos dois empreendimentos para a promoção/divulgação estão refletidos na tabela abaixo.

\section{CHAPADA IMPERIAL}

\begin{tabular}{|c|c|c|c|c|c|c|c|c|c|}
\hline PROPAGANDA & A & $\mathbf{M}$ & B & $\mathbf{T}$ & PROMOÇÃO DE VENDAS & A & $\mathbf{M}$ & B & $\bar{T}$ \\
\hline 4.1. Internet & & & & $x$ & 4.20. Preços promocionais & & & $\mathrm{x}$ & \\
\hline 4.2. Cinema & & & & & 4.21. Concursos & & & & \\
\hline 4.3. Televisão & & & & & 4.22. Cartões de desconto & & & & \\
\hline 4.4. Vídeo & & & & & 4.23. Cortesias & & & & $x$ \\
\hline 4.5. Rádio AM & & & & & 4.24. Comissão para guias & & & & $x$ \\
\hline 4.6. Rádio FM & & & & & 4.25. Mala direta & & & & \\
\hline 4.7. Revistas Nacionais & & & & & 4.26. Brindes & & & & $x$ \\
\hline 4.8. Revistas Internacionais & & & & & 4.27. Patrocínios & & & & \\
\hline 4.9. Mapas/folhetos/guias & & & & $\mathrm{x}$ & $\begin{array}{l}4.28 . \\
\text { Exposição/feiras/eventos }\end{array}$ & & & & $x$ \\
\hline 4.10. Panfletos & & & & $x$ & 4.29. Convênios & & & & \\
\hline
\end{tabular}




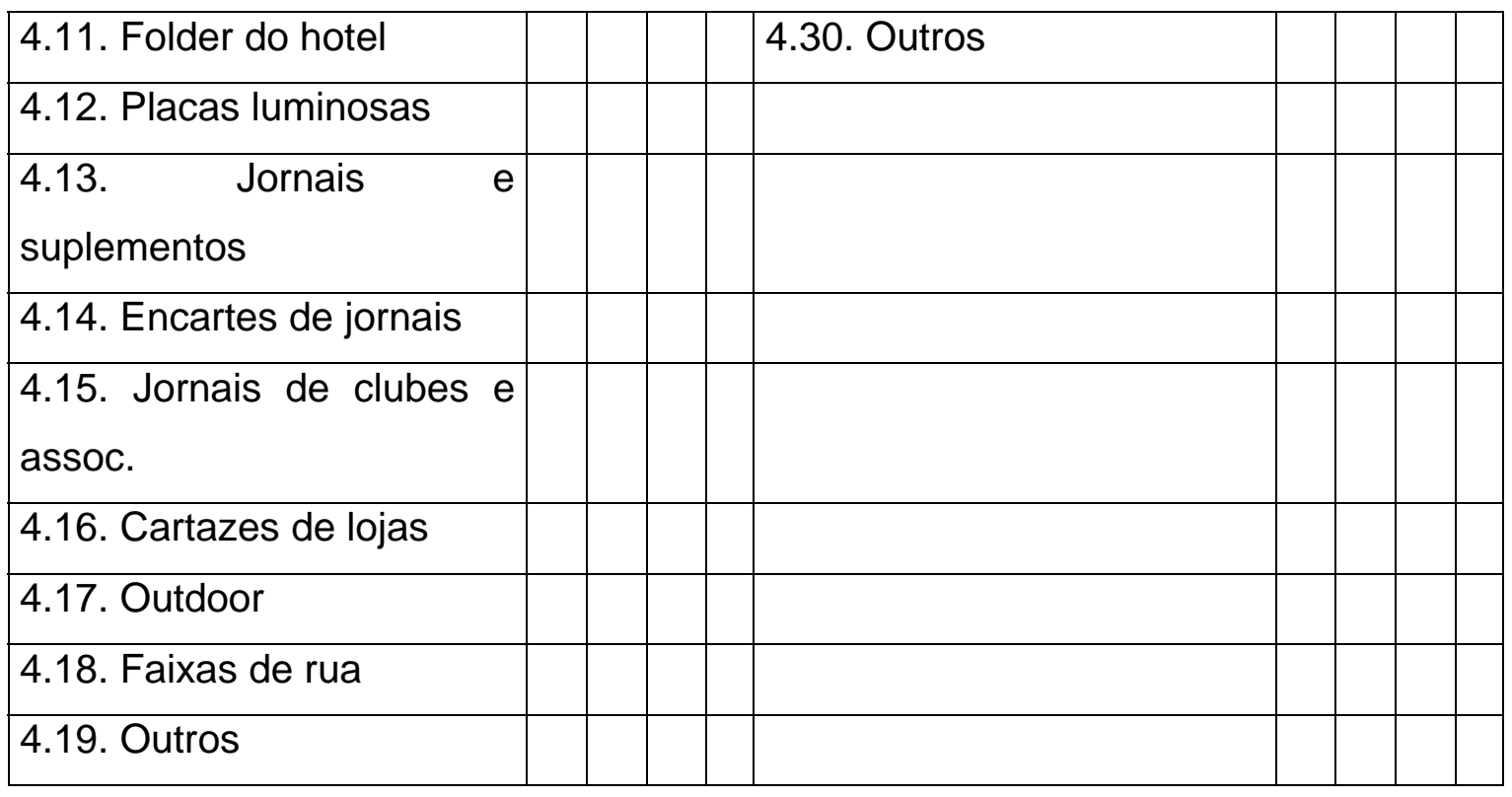

\begin{tabular}{|c|c|c|c|c|c|c|c|c|c|}
\hline VENDA PESSOAL & A & $\mathbf{M}$ & B & $\mathbf{T}$ & RELAÇÕES PÚBLICAS & A & $\mathbf{M}$ & B & $\bar{T}$ \\
\hline 4.31. Telemarketing & & & & & $\begin{array}{l}\text { 4.35. Contatos com } \\
\text { imprensa }\end{array}$ & & & & \\
\hline 4.32. Promotor de vendas & & & & $\mathrm{x}$ & $\begin{array}{ll}4.36 . & \text { Convites } \\
\text { especializados } & \end{array}$ & & & & \\
\hline $\begin{array}{l}\text { 4.33. Contatos com } \\
\text { operadoras }\end{array}$ & & & & & 4.37. Cartões fidelidade & & & & $x$ \\
\hline \multirow[t]{4}{*}{ 4.34. Outros } & & & & & 4.38. Cortesias à imprensa & & & & \\
\hline & & & & & $\begin{array}{l}\text { 4.39. SAC - Serviço de } \\
\text { Atendimento ao Cliente }\end{array}$ & & & & $x$ \\
\hline & & & & & 4.40. Fam-tours & & & & \\
\hline & & & & & 4.41. Outros & & & & \\
\hline
\end{tabular}

Legenda: A-alta estação; M-média estação; B-baixa estação; T-todas

FAZENDA VELHA

\begin{tabular}{|l|l|l|l|l|l|l|l|l|l|}
\hline PROPAGANDA & A & $\mathbf{M}$ & $\mathbf{B}$ & $\mathbf{T}$ & PROMOÇÃO DE VENDAS & $\mathbf{A}$ & $\mathbf{M}$ & $\mathbf{B}$ & $\mathbf{T}$ \\
\hline 4.1. Internet & & & & $\mathbf{x}$ & 4.20. Preços promocionais & & & $\mathrm{X}$ & \\
\hline 4.2. Cinema & & & & & 4.21. Concursos & & & \\
\hline 4.3. Televisão & & & & & 4.22. Cartões de desconto & & & $\mathrm{x}$ \\
\hline
\end{tabular}




\begin{tabular}{|c|c|c|c|c|}
\hline 4.4. Vídeo & & & 4.23. Cortesias & \\
\hline 4.5. Rádio AM & & & 4.24. Comissão para guias & $x$ \\
\hline 4.6. Rádio FM & & & 4.25. Mala direta & \\
\hline 4.7. Revistas Nacionais & & & 4.26. Brindes & \\
\hline 4.8. Revistas Internacionais & & & 4.27. Patrocínios & \\
\hline 4.9. Mapas/folhetos/guias & & & $\begin{array}{l}4.28 . \\
\text { Exposição/feiras/eventos }\end{array}$ & \\
\hline 4.10. Panfletos & & $\mathrm{x}$ & 4.29. Convênios & $\mathrm{x}$ \\
\hline 4.11. Folder do hotel & & & 4.30. Outros & \\
\hline 4.12. Placas luminosas & & & & \\
\hline $\begin{array}{l}\text { 4.13. Jornais e } \\
\text { suplementos }\end{array}$ & & & & \\
\hline 4.14. Encartes de jornais & & & & \\
\hline $\begin{array}{l}\text { 4.15. Jornais de clubes e } \\
\text { assoc. }\end{array}$ & & & & \\
\hline 4.16. Cartazes de lojas & & & & \\
\hline 4.17. Outdoor & & & & \\
\hline 4.18. Faixas de rua & $\mathrm{x}$ & & & \\
\hline 4.19. Outros & & & & \\
\hline
\end{tabular}

\begin{tabular}{|c|c|c|c|c|c|c|c|c|}
\hline VENDA PESSOAL & A & $\mathbf{M}$ & \begin{tabular}{l|l}
$\mathbf{B}$ & $\mathbf{T}$ \\
\end{tabular} & RELAÇÕES PÚBLICAS & A & $\mathbf{M}$ & B & $T$ \\
\hline 4.31. Telemarketing & & & & $\begin{array}{l}\text { 4.35. Contatos com } \\
\text { imprensa }\end{array}$ & & & & $x$ \\
\hline 4.32. Promotor de vendas & & & & $\begin{array}{ll}4.36 . & \text { Convites } \\
\text { especializados } & \end{array}$ & & & & \\
\hline $\begin{array}{l}\text { 4.33. Contatos com } \\
\text { operadoras }\end{array}$ & & & & 4.37. Cartões fidelidade & & & & $x$ \\
\hline 4.34. Outros & & & & 4.38. Cortesias à imprensa & & & & \\
\hline & & & & $\begin{array}{l}\text { 4.39. SAC - Serviço de } \\
\text { Atendimento ao Cliente }\end{array}$ & & & & \\
\hline & & & & 4.40. Fam-tours & & & & \\
\hline & & & & 4.41. Outros & & & & \\
\hline
\end{tabular}


Legenda: A-alta estação; M-média estação; B-baixa estação; T-todas

\section{Considerações finais}

O trabalho apresentado não é conclusivo, porém, à luz da análise e comparação dos dados levantados pode-se sugerir orientações norteadoras para um melhor resultado operacional dos empreendimentos.

Pode-se enfatizar algumas dificuldades percebidas no âmbito da investigação, como exemplo:

- ausência de marketing estratégico na divulgação dos empreendimentos;

- ineficiência na utilização da Internet como ferramenta de promoção e vendas;

- falta de direcionamento na comunicação com o público.

Constatou-se que os empreendimentos não utilizam toda a força promocional que a Internet oferece. Mantêm sites institucionais com caráter apenas informativo. Não os utilizam com outra finalidade senão a de informar ao público sobre algumas características do empreendimento. Nem mesmo todos os produtos e serviços disponíveis estão ali demonstrados. Hoje, um dos aplicativos no uso da Internet mais utilizados é a possibilidade da interatividade, onde o cliente pode acessar o site da empresa e executar serviços como: efetuar reserva e mesmo contratar os serviços via rede.

Com o atual perfil mundial formando uma "sociedade da informação" e, considerando - conforme constatado na pesquisa - o alto custo de veiculação dos meios de comunicação, é de fundamental importância concentrar as verbas promocionais em objetivos bem delimitados, ser seletivo, ser eficaz e não só eficiente no direcionamento da comunicação. No entanto, a pesquisa demonstrou o contrário. As respostas afirmando que atingem os mercados nacional, regional e internacional não corroboram com as afirmações que suas ações promocionais estão voltadas para o Distrito Federal. 
Foi percebida a ausência de uma estratégia de marketing para a utilização dos demais meios de comunicação tais como: televisão, jornais, revistas, outdoors. Meios largamente utilizados na comunicação promocional com retorno garantido, posto que ainda são válidas as conhecidas frases "a propaganda é a alma do negócio" e "quem não é visto não é lembrado". A esse respeito Cobra (1992), comenta que para vender um serviço, é preciso que o comprador em potencial tenha conhecimento deste. E, para tornar um serviço conhecido, há duas maneiras: a) uma lenta e gradual persuasão, decorrente da recomendação de quem já usou; b) outra decorrente do estímulo gerado pela divulgação do serviço. 


\section{Referências bibliográficas}

ACERENZA, Miguel Angel. Administração de turismo. Bauru-SP: EDUSC, 2002.

ANSARAH, Marilia Gomes. Turismo: segmentação de mercado. São Paulo: Futura,2002.

BENI, Mário Carlos. A política do turismo. In: TRIGO, Luiz Gonzaga Godoi (org.). Turismo como aprender, como ensinar. São Paulo: SENAC, 2001.

BOULLON, Roberto C. Proyectos turísticos: identificación, localización y dimensionamento. In: DENCKER, Ada de Freitas Manetti. Métodos e técnicas de pesquisa em turismo. - 2. ed. - São Paulo: Futura, 1998.

CARVALHO, Caio Luiz de. Na busca do turismo que queremos. In: LAGE, Beatriz Helena Gela; MILONE, Paulo César (org.) Turismo: Teoria e Prática. São Paulo: Atlas, 2000.

COBRA, Marcos. Administração em marketing - 2. ed. - São Paulo: Atlas, 1992.

COBRA, Marcos. Marketing de serviços. São Paulo: Cobra, 2001.

DENCKER, Ada de Freitas Maneti. Métodos e técnicas de pesquisa em turismo. São Paulo: Futura, 1998.

GIACOMINI, Gino Filho. Marketing: conteúdo, didático e perspectiva. In TRIGO, Luiz Gonzaga Godoi (org.). Turismo: Como aprender, como ensinar. São Paulo: Senac, 2001.

KOTLER, Philip. Administração de marketing. - 10. ed. - São Paulo: Prentice Hall, 2000. 
KRIPPENDORF, Jost. Sociologia do turismo: para uma nova compreensão do lazer e das viagens. São Paulo: Aleph, 2003.

KUAZAQUI, Edmir. Marketing turístico e de hospitalidade. São Paulo: Makron Books, 2002.

LAGE, Beatriz Helena Gales, MILONE, Paulo César. Bases para a elaboração de um trabalho científico no turismo. São Paulo: Atlas, 2000.

LAGE, Beatriz Helena Gales, MILONE, Paulo César. Economia do turismo. 7.ed. São Paulo: Atlas, 2001.

MALAGODI, Maria Eugênia; CESNIK, Fábio de Sá. Projetos culturais: elaboração, administração, aspectos legais e busca de patrocínio. - 2. ed. - São Paulo: Escrituras, 1999.

MIDDLETON, Victor T. C. Marketing de turismo: teoria e prática. - 3. ed. - Rio de Janeiro: Campus, 2002.

MIELENHAUSEN, Ulrich. Gestão do mix promocional para agências de viagens e turismo. In. LAGE, Beatriz Helena Gellas; MILONE, Paulo César. Turismo: teoria e prática. São Paulo. Atlas, 2000.

MOTA, Keila Cristina. Marketing Turístico: promovendo uma atividade sazonal. São Paulo: Atlas, 1999.

PETROCCHII, Mário. Turismo: planejamento e gestão. São Paulo: Futura, 1998.

RUSCHMANN, Doris Van de Meene. Marketing turístico: um enfoque promocional. Campinas: Papirus, 1990.

RUSCHMANN, Doris Van de Meene. Turismo e planejamento sustentável: a proteção do meio ambiente. - 6. ed. - Campinas: Papirus, 1997. 
SALVATI,Sérgio Salazar. Por uma política nacional de ecoturismo. Disponível em http://www.milenium.com.br/ilhas/PN.htm. acesso em 18.06.2004

SILVEIRA, Antônio R. dos Santos. Programa ambiental: a última Arca de Noé. Disponível em <http://www.aultimaarcadenoe.com)> Acesso em 20/07/2004. SWARBROOKE, John, Horner, Susan. O Comportamento do consumidor no turismo. São Paulo: Aleph, 2002.

TABARES, Fábio Cárdenas. Producto turístico: aplicación de la estadística y del mustreo para su disenõ. In: DENCKER, Ada de Freitas Manetti. Métodos e técnicas de pesquisa em turismo. - 2. ed. - São Paulo: Futura, 1998.

VAZ, Gil Nuno. Marketing turístico receptivo e emissivo: um roteiro estratégico para projetos mercadológicos públicos e privados. São Paulo: Pioneira, 1999.

WESTERN, David. Definindo ecoturismo. In: LINDBERG, Kreg. HAWKINS, E. Donald. (ed.). Ecoturismo: um guia para planejamento e gestão. - 2. ed. - São Paulo: Senac, 1999.

ZARDO, Eduardo Flávio. Marketing aplicado ao turismo: ferramentas de marketing para empresas de turismo e destinos turísticos. São Paulo: Roca, 2003.

ZEITHAML, Valarie A.; BITNER; Mary Jo. Marketing de serviços: a empresa com foco no cliente. - 2. ed. - Porto Alegre: Bookman, 2003. 


\section{Anexo}

\section{QUESTIONÁRIO DE PESQUISA}

\section{ESTRATÉGIAS PROMOCIONAIS DE EMPREENDIMENTOS ECOTURÍSTICOS DO ENTORNO DE BRASÍLIA}

I - IDENTIFICAÇÃO

1. Nome Fantasia:

2. Endereço:

3. Localidade mais próxima: distância: $\mathrm{km}$

4. Meios de acesso:

( ) ferroviário

( ) rodoviário ( ) pavimentado ( ) não pavimentado

5. Condições de acesso para:

5.1 - trailers, veículos e motor-homes ( ) boa ( ) regular ( ) ruim

5.2 - ônibus ( ) boa ( ) regular ( ) ruim

5.3 - vans, micro-ônibus $\quad$ ( ) boa $\quad$ ( ) regular ( ) ruim

6. Fone/Fax/E-mail: 
7. Tempo de existência do empreendimento: $\quad$ ( ) até 01 ano $\quad$ ( ) de 01 a 05 anos ( ) de 05 a 10 anos ( ) acima de 10 anos

8. Tipologia
( ) Hotel
( ) Hotel-fazenda
( ) Pousada
( ) Parque ( ) APA
( )

Parque Temático

\section{II - SAZONALIDADE}

1. Indique abaixo os meses que considera como sendo:

alta estação - A , média estação - M, baixa estação - B

\begin{tabular}{|l|l|l|l|l|l|l|l|l|l|l|l|}
\hline JAN & FEV & MAR & ABR & MAI & JUN & JUL & AGO & SET & OUT & NOV & DEZ \\
\hline & & & & & & & & & & & \\
\hline
\end{tabular}

2. Qual a taxa média de ocupação do empreendimento nos meses de:

alta estação:

\% média estação:

\% baixa estação:

$\%$

3. Na sua opinião o que poderia ser feito para reduzir a sazonalidade da demanda do seu empreendimento?

( ) mais propaganda e divulgação ( ) propaganda mais focada na clientela certa

( ) diversificar a clientela e implantar turismo de eventos ( ) tarifas promocionais

( ) melhorar os atrativos ( ) outros

4. Monta "pacotes" para baixa estação ( ) sim （ ) não

III - CLIENTE

1. O empreendimento faz ou contrata pesquisas para conhecer o cliente/mercado?

( ) $\operatorname{sim}($ ) não 
2. O empreendimento consulta pesquisas para conhecer o cliente/mercado? ( ) $\operatorname{sim}($ ) não

3. Qual a periodicidade da realização/consulta da pesquisa?

( ) mensal ( ) semestral ( ) anual

4. Qual o conteúdo/objetivo da realização da realização/consulta de pesquisas:

( ) perfil do cliente (demanda) ( ) qualidade do produto (oferta)

( ) avaliação da concorrência ( ) posicionamento - imagem do empreendimento no mercado ( ) avaliação de preços ( ) satisfação do consumidor

( ) outros

5. Você poderia indicar quais os maiores atrativos do local para os seus clientes:
( ) clima
( ) belezas naturais
( ) gastronomia ( ) hospitalidade
( ) diversões
( ) práticas esportivas
( ) outros

\section{IV - MERCADO}

1. Quais os mercados que atinge?
( ) local
( ) regional
( ) nacional
( ) internacional ( ) todos

2. Que outros mercados desejaria atingir?

( ) local ( ) regional ( ) nacional ( ) internacional ( ) nenhum

3. Qual o seu público-alvo?
( ) crianças
( ) jovens
( ) famílias
( ) melhor idade
( ) grupos de religiosos ( ) estudantes ( ) não é definido
( ) outros

4. Como é determinado o preço de venda do produto turístico? (aceita mais de uma resposta)

( ) verificando-se os custos de produção

( ) é colocada uma margem fixa de lucro 

( ) balizado pela concorrência
( ) acompanhando períodos de maior/ menor demanda
( ) outros

5. Como comercializa seu produto turístico?

(aceita mais de uma resposta)

( ) através de operadoras

( ) através de representantes de vendas

( ) venda direta

( ) outros

6. Tem apoio governamental para alguma iniciativa? ( ) sim ( ) não
7. Tem parcerias: ( ) sim
( ) públicas ( ) privadas
( ) não

\section{V - PROMOÇÃOIDIVULGAÇÃO}

1. Tem alguma assessoria de marketing contratada?
( ) $\operatorname{sim}$
( ) não

2. Qual a porcentagem do faturamento é investida em promoção e divulgação?
( ) $0-5 \%$
( ) $6-10 \%$
( ) $11-15 \%$
( ) nenhuma
( ) não sei

3. Realizou, nos últimos 2 anos, ações promocionais para divulgar o empreendimento?

( ) $\operatorname{sim}($ ) não

4. Quais os meios utilizados na promoção do empreendimento e seus serviços? (Marque x para aqueles utilizados na A - Alta estação; M - Média estação; B Baixa estação e T - Todas) 


\begin{tabular}{|c|c|c|c|c|c|c|c|c|c|}
\hline PROPAGANDA & A & $\mathbf{M}$ & B & $\mathbf{T}$ & PROMOÇÃO DE VENDAS & A & $\mathbf{M}$ & B & $\mathbf{T}$ \\
\hline 4.1. Internet & & & & & 4.20. Preços promocionais & & & & \\
\hline 4.2. Cinema & & & & & 4.21. Concursos & & & & \\
\hline 4.3. Televisão & & & & & 4.22. Cartões de desconto & & & & \\
\hline 4.4. Vídeo & & & & & 4.23. Cortesias & & & & \\
\hline 4.5. Rádio AM & & & & & 4.24. Comissão para guias & & & & \\
\hline 4.6. Rádio FM & & & & & 4.25. Mala direta & & & & \\
\hline 4.7. Revistas Nacionais & & & & & 4.26. Brindes & & & & \\
\hline 4.8. Revistas Internacionais & & & & & 4.27. Patrocínios & & & & \\
\hline 4.9. Mapas/folhetos/guias & & & & & $\begin{array}{l}4.28 . \\
\text { Exposição/feiras/eventos }\end{array}$ & & & & \\
\hline 4.10. Panfletos & & & & & 4.29. Convênios & & & & \\
\hline 4.11. Folder do hotel & & & & & 4.30. Outros & & & & \\
\hline 4.12. Placas luminosas & & & & & & & & & \\
\hline $\begin{array}{l}\text { 4.13. Jornais e } \\
\text { suplementos }\end{array}$ & & & & & & & & & \\
\hline 4.14. Encartes de jornais & & & & & & & & & \\
\hline $\begin{array}{l}\text { 4.15. Jornais de clubes e } \\
\text { assoc. }\end{array}$ & & & & & & & & & \\
\hline 4.16. Cartazes de lojas & & & & & & & & & \\
\hline 4.17. Outdoor & & & & & & & & & \\
\hline 4.18. Faixas de rua & & & & & & & & & \\
\hline 4.19. Outros & & & & & & & & & \\
\hline
\end{tabular}

\begin{tabular}{|c|c|c|c|c|c|c|c|c|c|}
\hline VENDA PESSOAL & A & $\mathbf{M}$ & B & $\mathbf{T}$ & RELAÇÕES PÚBLICAS & A & $\mathbf{M}$ & B & $\mathbf{T}$ \\
\hline 4.31. Telemarketing & & & & & $\begin{array}{l}\text { 4.35. Contatos com } \\
\text { imprensa }\end{array}$ & & & & \\
\hline 4.32. Promotor de vendas & & & & & $\begin{array}{ll}4.36 . & \text { Convites } \\
\text { especializados } & \end{array}$ & & & & \\
\hline $\begin{array}{l}\text { 4.33. Contatos com } \\
\text { operadoras }\end{array}$ & & & & & 4.37. Cartões fidelidade & & & & \\
\hline 4.34. Outros & & & & & 4.38. Cortesias à imprensa & & & & \\
\hline
\end{tabular}




\begin{tabular}{|l|l|l|l|l|l|l|l|l|}
\hline & & & $\begin{array}{l}\text { 4.39. SAC - Serviço de } \\
\text { Atendimento ao Cliente }\end{array}$ & & & \\
\hline & & & & $\begin{array}{l}4.40 . \text { Fam-tours } \\
4.41 . \text { Outros }\end{array}$ & & & \\
\hline
\end{tabular}

5. Onde são veiculadas as ações promocionais acima citadas?
( ) no DF
( ) em todo o Brasil ( ) em regiões específicas do Brasil
( ) outros

6. A divulgação do empreendimento é feita :
( ) pela administração do empreendimento
( ) por agências de propaganda
( ) outros

7. As ações promocionais estão inseridas num planejamento de marketing formal escrito?

( ) $\operatorname{sim}$ ( ) não

8. A divulgação é feita:

( ) com verba própria ( ) com verba financiada

( ) em conjunto com outros empreendimentos

( ) em conjunto com agências de turismo e operadoras

( ) outros

9. Qual o objetivo das ações promocionais?
( ) aumentar a demanda em geral
( ) diversificar a demanda
( ) divulgar um novo produto
( ) criar demanda na baixa estação
( ) outros

10. Quais os principais problemas enfrentados na divulgação dos produtos e serviços?

( ) falta de verba ( ) elevado custo da veiculação nos meios de comunicação

( ) dificuldade de definir o público-alvo e a melhor forma de atingi-lo

( ) outros 
Dados fornecidos por:

Cargo:

Data:

Fonte: Adaptado de MOTA, Keila Cristina. Marketing Turístico: promovendo uma atividade sazonal. São Paulo: Atlas, 1999. 